\title{
Yetenek yönetimi uygulamalarının işten ayrılma niyeti üzerindeki etkisi ve bu etkide ücret tatmininin aracılığının araştırılması
}

\section{Research of the impact of talent management practices on turnover intention and the mediation of compensation satisfaction in this effect}

\author{
Ercan Öge ${ }^{1}$ ii
}

Öz

${ }^{1}$ Dr., İstanbul Aydın Üniversitesi, İstanbul, Türkiye,

eoge@aydin.edu.tr

ORCID: 0000-0002-5529-1154

Başvuru/Submitted: 28/05/2021

Revizyon/Revised: 6/08/2021

Kabul/Accepted: 14/08/2021

Yayın/Online Published: 25/09/2021

Atıf/Citation: Öge, E., Yetenek yönetimi uygulamalarının işten ayrılma niyeti üzerindeki etkisi ve bu etkide ücret tatmininin aracılığının araştırılması, bmij (2021) 9 (3): 976-993, doi:

https://doi.org/10.15295/bmij.v9i3.1851
Amaç- COVID-19 pandemisi sonrası, iş yaşamında çok ciddi değişim ve dönüşümler beklenmektedir. İşletmeler, yeni koşullara uygun olarak yeniden yapılanma süreçlerini başlatırken, beraberinde yetenekli çalışana duydukları ihtiyaç her geçen gün daha da artmaktadır. Yeteneği elde tutmanın önemli unsurlarından biri olan, aldıkları ücretten duydukları tatmininin beklentilerini karşılamaması çalışanların işten ayrılma niyetini etkileyebilecektir. Bu araştırmanın amacı; yetenek yönetimi uygulamalarının işten ayrılma niyeti üzerindeki doğrudan ve aracı değişken olarak ücret tatmini etkisinin araştırılması olup, bu ilişkinin nasıl modellenebileceğini ortaya çıkarmaktır.

Metodoloji- İlişkisel tarama yöntemi ile yapılan araştırmanın örneklemi; faaliyetlerine devam eden bir tesis yönetim (Dış Kaynak Hizmeti Sağlayan) işletmesinin 200 çalışanından oluşmaktadır.

Bulgular- Yetenek yönetimi, ücret yönetimi ve işten ayrılma niyeti ilişkisine yönelik yapılan çalışma neticesinde; bağımlı değişken olarak yer alan işten ayrılma algısı ile hem somut hem de soyut yetenek yönetimi ilişkisinin negatif yönlü orta seviyeli bir ilişki içinde olduğu, yetenek yönetimi faktörlerinin ücret tatmini ile ilişkisinde ise oldukça yüksek pozitif korelasyon ve ücret tatmininin de oldukça güçlü bir mediatör yani aracı etkisine sahip olduğu sonucuna ulaşılmıştır.

Özgünlük- Literatürde, yetenek yönetimi, ücret tatmini ve işten ayrılma niyeti ilişkisine yönelik ayrı ayrı ya da ikili ilişkiler halinde incelenmiş çalışmalar olmasına rağmen, bu üç kavramın ilişkisini bir arada ele alan bir çalışmanın olmadığından yola çıkılarak, yapılan bu çalıșma ile literatüre bu yönde katkı sağlanmaya çalışılmıştır.

Anahtar Kelimeler: Yetenek Yönetimi, Ücret Tatmini Ve İşten Ayrılma Niyeti

Jel Kodları: O15, D23, M12

\begin{abstract}
Purpose- Severe changes and transformations are expected in business life after the COVID-19 pandemic. While organizations initiate their restructuring processes by new conditions, their need for talented employees increases day by day. Failure to meet employees' compensation satisfaction expectations, one of the critical elements of retaining talent, may affect turnover intention. The purpose of this study is to research the impact of talent management practices directly on turnover intention and as an intermediary variable on compensation satisfaction and to reveal how this relationship will be modelled.
\end{abstract}

Methodology - The study sample, conducted with the correlational survey method, consists of 200 employees of a facility management (Outsourcing Service Provider) organization that continues its activities.

Findings- As a result of the study on the relationship between talent management, compensation management, and turnover intention, the perception of leaving the job as the dependent variable has a negative and moderate relationship with tangible and intangible talent management. Moreover, there is a very high positive correlation between talent management factors; and compensation satisfaction and compensation satisfaction have a powerful intermediary effect.

Originality- Although there are studies in the literature that have examined the relationship between talent management, compensation satisfaction and turnover intention, separately or as bilateral relations, considering that there is no study that deals with the relationship of these three concepts together, with this study, it has been tried to contribute to the literature in this direction.

Keywords: Talent Management, Compensation Satisfaction, Turnover Intention

Jel Codes: O15, D23, M12 


\section{Extended Abstract} Research of the impact of talent management practices on turnover intention and the mediation of
compensation satisfaction in this effect

\section{Literature}

\section{Research subject}

The subjects of the research consist of talent management, compensation satisfaction and turnover intention. Considering the titles of the research; in their studies, Akbaş (2013) has reached the conclusion that organizations' practices towards their employees' talents increase the willingness of the employees to stay in the organization; Boz (2016) has reached the conclusion that talent management perceptions directly affect turnover intention; Tümen (2014) has reached the conclusion that correct application of talent management reduces employee turnover intention; Aslantaş (2016) and Ertekin (2019) have reached the conclusion that there is a negative significant relationship between talent management and turnover intention; Tarakçı and Öneren (2016) have reached the conclusion that talent management negatively affects turnover intention; Türk and Akbaba (2017) have reached the conclusion that employees' talent management perception decreases their turnover intention; Alyay (2019) has reached the conclusion that a high level of satisfaction regarding talent management will make it easier to overcome employee loss; Yeni (2020) has reached the conclusion that perceived talent management negatively affects turnover intention; Abdul Latif, Saraih, and Harada (2020) have reached the conclusion that talent management practices affect employees' turnover intentions and may reduce their turnover intention; Dalahmeh, Heder and Dajnoki (2020) have reached the conclusion that talent management practices of organizations reduce the employee's turnover intention.

When the relationship between compensation satisfaction and turnover intention is examined; Kanten, Kanten and Dündar (2016) have concluded that turnover intention of the employees who are satisfied with the organization's pay structure decrease; Seçkin and Çoban (2017) have concluded that as employees' satisfaction with their wage levels increase, their intention to stay in the organization increase. Moreover, Naidoo (2017) has concluded that compensation satisfaction partially mediates its effect on turnover intention, and Putri (2020) has concluded that the higher the compensation satisfaction of generation $Y$ employees, the lower their turnover intention will be.

\section{Research purpose and importance}

The purpose of this study is to research the impact of talent management practices directly on turnover intention and as an intermediary variable on compensation satisfaction and to reveal how this relationship will be modelled. The lack of a study, which deals with the relationship between the three concepts that constitute the research subject, makes the study significant.

\section{Contribution of the article to the literature}

Although there are studies in the literature that have examined the relationship between talent management, compensation satisfaction and turnover intention, separately or as bilateral relations, considering that there is no study that deals with the relationship of these three concepts together, with this study, it has been tried to contribute to the literature in this direction.

\section{Design and method}

\section{Research type}

This study is a quantitative designed study that has been conducted with a correlational survey method. The correlational survey method is the type of research that includes at least one independent variable associated with a dependent variable. The dependent variable of the research is turnover intention. Its independent variable is talent management. Compensation satisfaction is considered an intermediary variable.

\section{Research problems}

The research problem is; to determine the effect of talent management practices (perception) on turnover intention and determine whether compensation satisfaction has a mediating role as an intermediary variable.

\section{Data collection method}

In the research, the survey method has been used as the data collection technique. The data collection form questionnaire consists of four sections. The first section contains socio-demographic information. The second section includes Talent Management Scale, the third section includes Compensation Satisfaction Scale, and the fourth section includes the Turnover Intention Scale.

\section{Quantitative/qualitative analysis}

Reliability analysis of Talent Management Scale, Turnover Intention Scale and Compensation Satisfaction Scale, which have been used in the research, was conducted first separately and then together and in order to perform the factor analysis, the assumptions had to be provided first, and for these assumptions, Kaiser Meyer measure of sampling adequacy and Bartlett's test have been performed. Then, estimates have been made; by using correlation analysis in order to show the strength, direction and significance of the relationship between all factors which have been considered as dependent, independent and intermediary and by using various regression equations in order to determine whether the compensation factor has such a role as a mediator, in other words, intermediary effect.

\section{Research model}

The research model, including Talent Management, Turnover Intention and Compensation Satisfaction Variables, is presented below. 


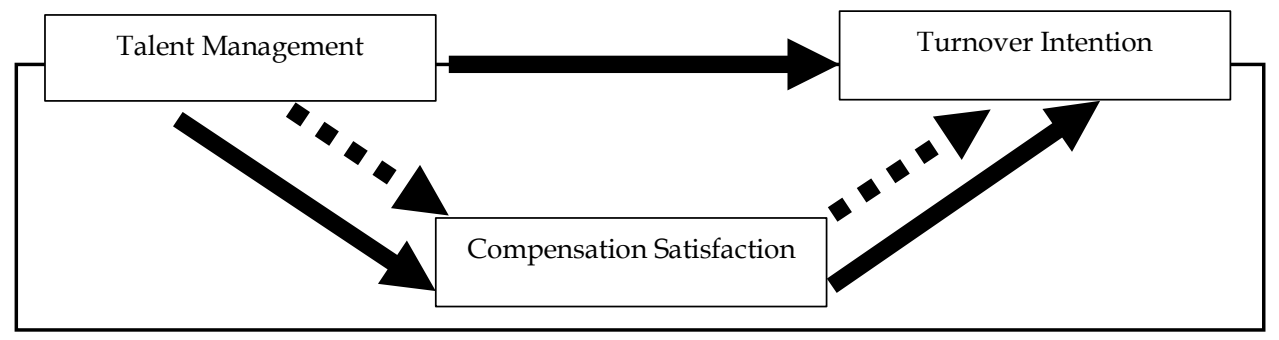

Research hypotheses

Research Hypotheses;

Talent management practices have an impact on turnover intention

The intangible and tangible factors impact the compensation of the talent management sub-factors, which is considered the intermediary variable.

Talent management practices and compensation satisfaction, which is considered an intermediary variable, impact turnover intention.

\section{Findings and discussion}

\section{Findings as a result of analysis}

As a result of the analysis of the study, it has been concluded that; in organizations with firm talent management practices, the turnover intention will be lower, or on the contrary, in organizations that find talents but fail to strengthen and retain them, the turnover intention will be higher. Moreover, with regression analysis, intangible and tangible talent management perceptions have significant explanatory power on the dependent turnover intention variable. Besides, due to the causality relationship of tangible and intangible talent management perceptions separately on the compensation factor, which is considered the intermediary variable, both have significant $F$ values and relatively strong $R^{2}$ values on the dependent variable. For example, this value is 0.392 with the intangible factor and 0.423 with the genuine factor. Thus, the most critical finding in the study is that the compensation factor has a powerful mediator effect, in other words, the intermediary effect.

\section{Hypothesis test results}

According to research analysis results, the turnover intention will be lower in firms with firm talent management practices. On the contrary, the turnover intention will be higher in organizations that find talents but fail to strengthen and retain them. Therefore, the first hypothesis is accepted; based on the result that tangible and intangible talent management perceptions have significant $\mathrm{F}$ values and R2 values, which can be considered quite strong, the second hypothesis is accepted on the dependent variable. Finally, based on the result that the most critical finding in the study is that the compensation factor has a powerful mediator effect, intermediary effect, the third hypothesis is accepted.

\section{Discussing the findings with the literature}

The result which has been achieved as "turnover intention will be lower in organizations with strong talent management practices, or on the contrary, turnover intention will be higher in organizations which find talents but fail to strengthen and retain them", supports the study results of Akbaş (2013); Tümen (2014); Tarakçı and Öneren (2016); Boz (2016); Aslantaş (2016) and Ertekin (2019); Türk and Akbaba (2017); Alyay (2019); Yeni (2020); Abdul Latif, Saraih, and Harada (2020); Dalahmeh, Heder and Dajnoki (2020) in the literature regarding this subject.

In the study, the result, that turnover intention is affected by the compensation factor based on the factor that it has a powerful mediator effect, in other words, intermediary effect, supports the study results of Kanten, Kanten and Dündar (2016); Seçkin and Çoban (2017); Naidoo, (2017) and Putri (2020) in the literature regarding this subject.

\section{Conclusion, recommendation and limitations}

\section{Results of the article}

Turnover Perception, a dependent variable in the network of relationships where Talent Management Perception, Compensation Satisfaction and Turnover Intention factors are evaluated together, has a negative, moderate relationship with tangible and intangible talent management. In contrast, tangible and intangible talent management factors have a highly positively correlated relationship with compensation satisfaction. In this context, it should be expected that turnover intention would be lower in the organizations with strong talent management practices or, on the contrary, that turnover intention will be higher in the organizations where talent management practices are inadequate.

When the causality relationship of the tangible and intangible sub-dimensions of talent management, with intermediary variable compensation factor, is examined separately, it is observed that there is a significant effect on compensation satisfaction. Besides, the most critical finding obtained in the study is that compensation satisfaction has a powerful mediator effect, in other words, intermediary effect.

\section{Suggestions based on results}

When the variables used in the study are considered, it should be expected that this study will contribute to the literature in research conducted in different sectors. Moreover, to attract talented employees, they need in this intensely competitive environment, the organizations need to align their pay strategies with current business life conditions to create solutions in terms of their sustainability and in terms of reducing turnover intention of talented employees.

\section{Limitations of the article}

The limitation of this study is that it is limited to the employees of a facility management organization operating in Istanbul. 


\section{Giriş}

Küresel rekabet ortamında ortaya çıkan zorlayıcı birçok faktör, örgütlerin varlıklarını devam ettirmelerinde ciddi tehdit oluşturmaktadır. Bu durum, işletmelerin "yetenek yönetimi" çalışmalarına ve "yetenekli çalışanlara" olan ihtiyacını arttırmaktadır. Yetenek yönetimi, sadece insan kaynakları birimlerine bırakılmayacak kadar önemli ve çok boyutlu bir stratejik konudur (Keçecioğlu ve Aydın, 2017, s.13). Genelde üst yönetim tarafından yapılandırılan ve uygulanan insan kaynakları yönetimi uygulamaları, günümüzün değişken ve dinamik iş yaşamında işletmelerin üst düzey başarı sağlamalarında ciddi katkı sağlamaktadır (Kanten, Kanten ve Dündar, 2016, s.65). Dolayısıyla makro anlamda bir yönetim stratejisi olan "yetenek yönetimi" ile insan kaynakları uygulamalarının uyumlu hale getirilmesi örgütlerin yetenekli çalışanlarını etkin ve verimli bir şekilde değerlendirebilmelerine olanak sağlarken, devamlılıkları açısından da stratejik bir rol üstlenecektir.

Yetenekli işgücünün, işletmeye çekilmesi ve elde tutulmasında örgütlerin yararlandıkları insan kaynakları uygulamalarından biri de "ücret yönetimi"dir. Ücret yönetimi, işletmenin amaç ve hedeflerini gerçekleştirmek amacıyla gerekli insan kaynağını işletmeye çekme, elde tutma; iş tatmini ve motivasyonunu sağlama, bireysel ve örgütsel başarıyı gerçekleştirme, yasal ve çevresel koşullara uyma amaçları doğrultusundaki konularda çalışanların ücretlerine ilişkin yapı, sistem politika ve uygulamaları içermektedir (Acar, 2007, s.1). Başarılı bir ücret yönetiminin ücret tatmini üzerinde önemli etkisi söz konusudur. Dolayısıyla örgütsel bağlılık, iş başarısı, iş motivasyonu ve işten ayrılma niyeti gibi kurumsal yönden önem arz eden çeşitli sonuçlar üzerinde belirleyici bir etkiye sahip olan ücret tatmini (Li, 2015, s. 1), çalışanların işten ayrılma niyetinin bir öncülü olarak dikkate alınmalıdır (Öge ve Çetin, 2019, s.542).

Kurumun ortaya koyacağı performans yönünden yüksek öneme sahip bir çalışan tutumu olan işten ayrılma niyeti, örgütlerde ciddi olumsuz sonuçlar yaratmaktadır. Yetenekli çalışanların, ücret tatminsizliğinden dolayı işten gönülsüz şekilde ayrılmaları diğer yandan çalışma hayatında ciddi oranda varlıklarını hissettiren Y kuşağının daha sık iş değiştirmesi, verimlilik ve üretkenliği olumsuz etkilemesi, işten ayrılma ve işten ayrılma niyetini işletmeler açısından çözüme kavuşturulması gereken bir olgu olarak ön plana çıkarmıştır (Öge ve Çetin, 2019, s.544). Dolayısıyla ücret tatmini, çalışanın işletmede kalma veya işletmeden ayrılma kararı vermesini etkileyen en önemli faktörlerden birisi olarak değerlendirilirken (Kanten, Kanten ve Dündar, 2016, s.65), çalışanların aldıkları ücretten duydukları tatminin artması da işte kalma niyetlerini olumlu yönde etkileyecektir. Bu amaçla çalışmada; yetenek yönetimi uygulamalarının çalışanların işten ayrılma niyetine olan etkisi ve beraberinde yetenekli çalışanların işten ayrılma niyetine olan etkisi üzerinde ücret tatminin aracı değişken rolünün açıklanmasıyla ilgili yazına katkı sağlanması beklenmektedir.

\section{Yetenek yönetimi}

İnsan kaynakları yönetimi literatüründe son zamanlarda en çok gündeme gelen, üzerinde tartışılan ve vurgulanan kavram "yetenek"tir. Küreselleşme ve beraberinde yaşanan yoğun rekabet karşısında rakiplere karşı üstünlük elde edebilmenin yolunun müşterilere farklı ya da benzersiz ürün ve hizmet sunabilmek, bunu gerçekleştirebilmenin çözüm yolu ise, nitelikli çalışanların sahip oldukları yeteneklerinin işletme süreçlerinin her kademesinde etkili ve doğru ve şekilde değerlendirilmesi olduğu konusunda görüş birliği oluşmaya başlamıştır. Bu nedenle, işletmeler açısından "insanların yönetimi" nden ziyade "yeteneklerin yönetimi" önem kazanmaya başlamıştır (Alayoğlu, 2010:74-75). Yetenek yönetimi, örgütün hangi iş pozisyonları doldurulması gerektiğini ve çalışanların bu işleri etkili bir biçimde yapmaları amacıyla ihtiyaç duydukları beşerî özellikler ve yetkinliklerin anlaşılması ile başlamaktadır (Dessler, 2019, s.97). Yetenek yönetiminde amaç, çalışanların yeteneklerini değerlendirerek hangi konularda daha başarılı olabileceklerini ortaya çıkarmak ve o yönde değerlendirmektir (Ergeneli, İlsev, Camgöz, Kümbül Güler, Bayhan Karapınar, Tayfur Ekmekçi, Ferendeci Özgödek, Gözde Özgödek, Atalay Odabaşı ve Akşirin Borluk, 2014, s.263). Başka bir ifadeyle, örgütün yüksek performans ortaya koyması amacıyla çalışanların yeteneklerinin, örgütün hedefleri ile uyumlu hale getirilmesidir (Bayraktar, 2019, s.38). Yetenek yönetimi; örgütün gelecekte ortaya çıkabilecek iş ihtiyaçlarını karşılama ve stratejik iş hedeflerine ulaşmak amacıyla yetenekleri kendisine çekebilme, geliştirme ve elde tutmada kurum tarafından tasarlanmış ve uygulanmış süreçler ve programların bütünleştirilmiş hali (Keçecioğlu ve Korkmaz Çiçek, 2014, s.155), insan kaynağının planlaması, işe alımı, geliştirilmesi, yönetimi ve ücretlendirilmeleri ile ilgili amaç odaklı ve bütünleşik bir süreçtir (Dessler, 2019, s.96).

Organizasyonların birçoğunda kurumsal stratejilerin önemli bir bileşeni haline gelen (Bano, Khan, Rehman ve Humayoun, 2010, s.5) yetenek yönetimi, organizasyondaki insan sermayesine yönelik stratejik bir yaklaşımdır (Bayraktar, 2019, s.38). Örgütler, iş stratejilerini gerçekleştirebilmek amacıyla 
yararlanabileceği yetenekli çalışanlardan emin olabilmek amacıyla beş temel süreçten yararlanırken, insan kaynakları yönetimi programları, sistemleri ve süreçlerinin bu beş yetenek süreci ile ilişkili olduğu söylenebilir. Bu süreçler (Keçecioğlu ve Aydın, 2017, s.118-119);

- Örgüte yeteneği çekmek ve seçmek

- Yeteneklerdeki yetkinlikleri ve yapabilirlikleri değerlendirmek

- Yetenek eylemlerini planlamak ve yeteneklerle görüşmek

- Yeteneği geliştirmek ve yaymak

- Yeteneği elde tutmak ve bağlllığı sağlamak şeklindedir.

Bu beş temel sürece yönelik Yetenek Yönetimi Çerçevesi modeli Şekil 1'de gösterilmiştir.

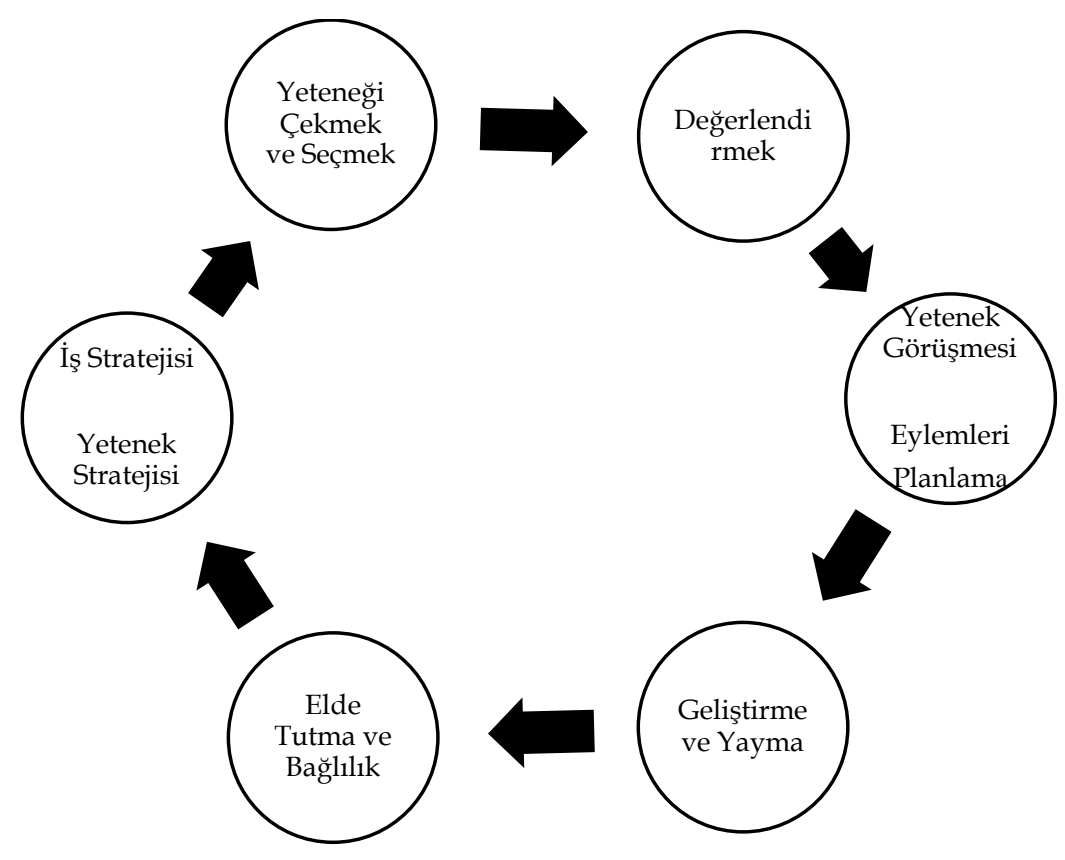

Şekil 1. Yetenek Yönetimi Çerçevesi

Kaynak: Keçecioğlu, T. ve Aydın, G.G. (2017).

\section{Ücret tatmini}

Çok yönlü ve karmaşık bir olgu olarak ücret, ekonomik ve sosyal yaşamın hemen hemen tüm alanlarını etkileyebilmektedir (Uyargil, Özçelik, Acar, Dündar, Ataay, Tüzüner, Sadullah ve Adal, 2018, s.353). En kapsamlı anlamıla ücret; çalışma veya iş yapma karşılığında çalışanlara sağlanan maddi veya maddi olmayan "tüm yararları" veya "ödüller" şeklinde tanımlanabilir (Acar, 2007, s.8). İşgörenlerin refah düzeyinin belirlenmesinde ve temel ihtiyaçlarının karşılanmasında ücret önemli bir araç ön plana çıkmaktadır (Topalhan, 2014, s.10). Çalışanların örgütsel yaşamdaki olumlu ve olumsuz tutum ve davranışlarının kritik bir belirleyicisi olarak değerlendirilen ücret tatmini (Kanten, Kanten ve Dündar, 2016, s.657); iş tatmininin temel yapıtaşlarından birisi olarak, işletmelerin çalışanlarını motive etmede ve elde tutmada kullanıldıkları önemli bir araç ve aynı zamanda çalışanların işte kalma niyeti üzerinde pozitif yönde bir etkisi olduğu ifade edilmektedir (Seçkin ve Çoban, 2017, s.135-136).

Ücret tatmini ise; çalışanların örgütsel amaçlar doğrultusunda ortaya koydukları çabaları karşıllığında elde ettikleri ücretin bütününe yönelik olumlu duygulara sahip olması (Kanten, Kanten ve Dündar, 2016, s.65); çalışanların aldığı ücrete ilişkin duydukları tatmin düzeyi (Seçkin ve Çoban, 2017, s.135) şeklinde ifade edilebilir. Ücret tatmini, çalışanın ücrete ilişkin beklentisi ile gerçekleşen ücret ödemesi arasındaki farkın en az düzeyde gerçekleşmesiyle ortaya çıarken (Çakır, 2006, s.124) işgörenlerin ücret tatmini, elde ettiği ücretten mutlu olmasıyla birlikte ücretin adil bir şekilde belirlenmesi, diğer benzer sorumluluk ve iş yükü sahip çalışma arkadaşlarının gelirine kıyasla hakkaniyetli olması, işgörenin fazladan katkı ve performansına ücret (ya da prim) ile karşıllk verilmesi ve işgörenin elde ettiği ücretin tutarlılığına ve sürekliliğine güven duymasıyla alakalıdır (Ataay, 1985, s.254-255). Bu nedenle, çalışanların aldıkları ücrete ilişkin düşünceleri adil bir algılama yönünde ise ücret tatminlerinin de bu algılamaya bağlı olarak yüksek olması beklenmelidir (Luthans, 1998, s.114). Yapılan araştırmalar; ücret tatmininin işten ayrılma niyeti, düşük iş performansı, işe geç gelme ve devamsızlık ile negatif; iş tatmini ve örgütsel vatandaşlık ile de pozitif yönde ilişkili olduğunu ortaya koyarken, bununla birlikte yapılan 
diğer bazı araştırmalar ise ücret tatmininin işte kalma niyeti üzerinde pozitif yönde bir etkisi olduğunu ortaya koymuştur (Seçkin ve Çoban, 2017, s.135-136).

\section{İşten ayrılma niyeti}

Çalışanların işten ayrılma davranışının bir öncülü olarak düşünülen işten ayrılma niyeti, son yıllarda örgütsel davranış alan yazınında araştırmacıların yoğun bir şekilde ilgilendikleri konuların başında gelmektedir (Seyfullahoğulları, 2018, s.57). Alanyazında işten ayrılma niyeti kavramı ile çok net bir tanım olmamakla birlikte farklı araştırmacılar tarafından ortaya konulan bazı tanımlar şu şekildedir: Mobley (1982)'e göre, çalışanın yakın bir zamanda işini bırakmaya yönelik düşüncesi; Tüzün (2007)'e göre, çalışanın işini bırakma eğiliminde olması; Özdemir ve Özdemir (2015)'e göre kişisel ve/veya örgütsel beklentilerin karşılanamaması sonucunda çalışanlarda ortaya çıkan iş ilişkisini bitirme ve işletmeyi bırakma isteği; Yücel ve Demirel (2013)'e göre, bir çalışanın işletmeden ayrılmayı planlaması veya düşünmesi; Fong ve Mahfar (2013)'a göre ise, çalışanın işletmeden ayrılmadan önceki sürece kadar geçen sürede ayrılma plan ve düşüncesine sahip olmasıdır.

İşten ayrılmanın bir öncülü olarak çalışanların işten ayrılma niyeti çeşitli faktörlerden (nedenlerden) kaynaklanmaktadır. Bu faktörler; bireysel, çevresel ve işletmeye ait faktörler (nedenler) şeklinde ifade edilebilir (Seyfullahoğulları, 2018, s.53). İşten ayrılma niyetinin gönüllü ve gönülsüz şeklinde iki türünden bahsedilebilir. Gönüllü işten ayrılma niyeti, çalışanın kendi isteği ile çalıştığı kurumun dışına çıkma ihtimalini, gönülsüz işten ayrılma niyeti ise çalışanın kendi isteği dışında çalıştığı kurumda ortaya çıkan nedenlerden dolayı işinden ayrılma eğiliminde olmasını belirtmektedir. Gönüllü işten ayrılma niyetinin nedenlerinden biri de ücret ve çalışma koşuludur (Yeni, 2020, s.43-44). İşten ayrılma niyeti, ücret tatminsizliğinin olumsuz sonuçlarından biridir. İşten ayrılma niyeti hangi nedenden kaynaklanırsa kaynaklansın işletmeye yaratacağı maliyet açısından dikkate alınması gereklidir. İşten ayrılma niyetinde olan bir çalışanın, mevcut işine devam etmesi birçok açıdan değerlendirilmesi gereken bir durumdur. Çalışanın halen işine devam ediyor olması, başta maliyetler olmak üzere, kurumda yer alan diğer çalışanlara yönelik sosyal ilişkilerin olumsuz olmasına ve beraberinde zaman kaybettirici bir unsura dönüşebilecektir (Poyraz ve Kama, 2008, s.149).

\section{Yetenek yönetimi, ücret tatmini, işten ayrılma niyeti arasındaki ilişkiler}

Yetenekli çalışan ihtiyacı, bu yetenekli çalışanları işletmeye çekmek ve elde tutmak örgütleri zorlayıcı konuların başında gelmektedir. Yetenekli çalışanlara sahip örgütler, çeşitli nedenlerden dolayı bu yetenekleri bünyelerinde istihdam edememektedirler. Bu durum, örgütün işe alım maliyetlerine olumsuz yansırken aynı zamanda sürdürülebilir rekabet açısından olumsuz etkilemektedir. Örgütte işten ayrılma niyetine yönelik oluşacak olumsuz süreç diğer çalışanlar üzerinde moral bozukluğu yaratmakla birlikte işten ayrılma sürecini de huzlandırabilmektedir. İşten ayrılma niyeti olan çalışanların, potansiyel ve yüksek nitelikte olması örgütler açısından stratejik bir bakış açısı ile değerlendirmeleri gereken bir husustur. Çünkü örgütler, işgücü devir oranını incelerken dikkate almaları gereken husus, kaç kişinin işten ayrıldığı değil, ayrılanların performansları ve telafi edilebilirliğidir. Normal koşullarda, örgütlerde isteğe bağlı ayrılmalar, istek dışı ayrılmalardan daha fazla olduğu için örgütler isteğe bağlı ayrılmalar konusuna daha fazla yoğunlaşmalı, yetenekleri örgütte tutmanın çözümleri aramalı ve üretmelidir (Tüzüner, 2011, s.206).

Üretim yapan veya hizmet veren işletmelerin faaliyetlerini gerçekleştirebilmek amacıyla ihtiyaç duyduğu yetenekteki çalışanı istihdam edemeyen veya elinde tutamayan örgütlerin varlıklarını devam ettirme imkânı söz konusu olmayacaktır (Demir, 2020, s.91). Bu amaçla da işletmelerin iyi bir ücret ve ödül sistemi ile üstün yetenekli işgörenlerin örgüte çekilmesi (işveren markasının bir boyutu olarak) ve mevcut çalışanlarını da bünyelerinde tutabilmek amacıyla daha fazla gayret göstermelidir. Örgütlerin çalışanlarının ortaya koydukları çaba ve verdikleri katkıların karşılığını ücretlerine yansıtmaları, aldıkları ücretin yeterli ve adil olduğuna yönelik algıyı tesis etmesi yani ücret tatminlerinin olması bu yeteneklerin işletmede kalmaları niyetleri açısından önemlidir (Demir, 2020, s.91; Gürbüz, 2019, s.269).

\section{Araştırma yöntemi}

Bu araştırma kapsamında, faaliyetlerine devam eden bir tesis yönetim (Dış Kaynak Hizmeti Sağlayan) işletmesinin çalışanlarında; yetenek yönetimi uygulamalarının (algısının) işten ayrılma niyeti üstündeki etkisini belirlemek ve beraberinde ücret tatminini aracı değişkeninin bir aracılık rolünün olup olmadığının tespiti amacıyla nicel paradigma kapsamında karma model (betimsel model, ilişkisel model, karşılaştırmalı model, aracılık etki rolü) kullanılmıştır. Değişkenleri içeren araştırma modeli Şekil 2'de sunulmuştur. 


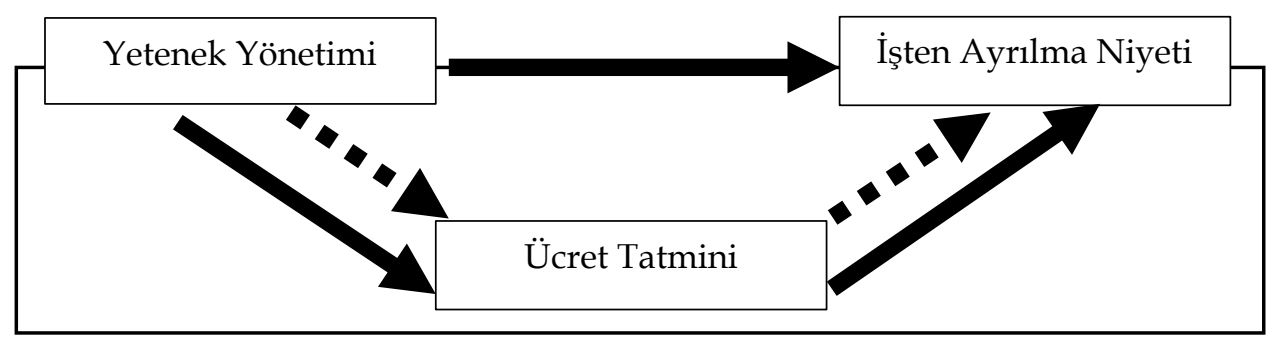

Şekil 2: Araştırmanın Modeli

Bu çalışma ilişkisel tarama yöntemi ile yapılmış nicel desenli bir çalışmadır. İlişkisel tarama yöntemi bir bağımlı değişkenin ilişkili olduğu en az bir bağımsız değişken barındıran araştırma türüdür. Araştırmanın bağımlı değişkeni işten ayrılma niyetidir. Bağımsız değişkeni yetenek yönetimidir. Ücret tatminini ise aracı bir değişken olarak ele alınmıştır.

\section{Evren ve örneklem}

Örnekleme yönteminde temel amaç, seçilen örneklemin evreni temsil edebilecek özellikte olmasıdır. Çalışmada araştırma evreni (2021 yılının ilk üç ayında toplanarak) faaliyetlerine devam eden bir dış kaynak hizmeti sağlayan büyük bir tesisin 47.000 kişilik çalışanının İstanbul Anadolu yakası genelindeki 16.000 kişilik bir grup oluşturmaktadır. \%95 güven aralığında yaklaşık \%6,5 hata payı ile araştırmada zaman kıstı ve örnekleme ulaşım zorluğundan dolayı olasılığa dayalı olmayan, tesadüfi olmayan örnekleme yöntemlerinden "Kolayda Örnekleme Yöntemi" tercih edilmiştir. Bu yöntemde veriler, ana kütleden kolay ve hızlı bir şekilde toplanmaktadır (Malhotra, 2004). Toplam 210 kişiye ulaşılsa da eksik ve yanlış veri girişi ile bu sayı 200'e düşmüştür. Elde edilen örneklem sayısı da zaten hata payı ve güven aralığına uygun bir değerdedir.

\section{Veri toplama araçları}

Veri toplama formu dört bölümden oluşmaktadır. Birinci bölümde sosyo-demografik bilgiler bulunmaktadır. İkinci bölümde Yetenek Yönetimi Ölçeği, üçüncü bölümde ise Ücret Tatmini Ölçeği ve dördüncü bölümde ise İșten Ayrılma Niyeti Ölçeği bulunmaktadır.

Sosyo-Demografik Sorular şunlardan oluşmaktadır: Cinsiyet, yaş, eğitim durumu, medeni durumu, aylık gelir, çocuk sahibi olma durumu, aynı evde bakmakla yükümlü oldukları kişiler ve sayısı, pozisyon ünvanı ve işletmedeki çalıştığı süre

Yetenek Yönetim Ölçeği: 2006 yılında Society for Human Resource Management aracilığıyla Shawn Fegley (2006) tarafından geliştirilen ve 16 maddeden oluşan Yetenek Yönetimi Uygulamaları Algısı Ölçeği, Hande Serim Bahadınlı (2013) tarafından Türkçeye çevrilmiştir. Beşli likert tipi ölçekte; somut ve soyut faktörler olmak üzere iki alt boyut bulunmaktadır.

Ücret Tatmini Algısı Ölçeği: Heneman ve Schwab (1985) tarafından geliştirilen ve 13 maddeden oluşan Ücret Tatmini Ölçeği, Özlem Ergüney (2006) tarafından Türkçeye uyarlanmıştır. Beşli likert tipi ölçekte; ücret düzeyi tatmini, ücret yapısı tatmini, ücret artışları tatmini alt boyutlarından oluşmaktadır.

İşten Ayrılma Niyeti Ölçeği: Wayne, Shore ve Liden (1997) tarafından geliştirilip, Küçükusta (2007) tarafından Türkçeye uyarlanan "İşten Ayrılma Niyeti Ölçeği", tek boyutta toplanmış 3 maddeden oluşmaktadır üç ifadeden oluşmakta ve tek boyutludur. Araştırmada cevaplar 5'li Likert ölçeği kullanılarak toplanmıştır.

\section{Bulgular}

Çalışma modelinde temel olarak ölçmek istenilen; yetenek yönetimi uygulamalarının (algısının) işten ayrılma niyeti üzerindeki etkisini belirlemek, ayrıca ücret tatmininin aracı değişken olarak bir aracılık rolünün olup olmadığının tespit etmektir.

Araştırmada kullanılan Yetenek Yönetimi, İşten Ayrılma Niyeti ve Ücret Tatmini ölçekleri önce ayrı ayrı, daha sonra birlikte güvenilirlik analizine tabi tutulmuş, sonuçlar değerlendirilmiş ve güvenilirliği düşüren sorular olmadığından herhangi bir ölçek maddesi çıkarılmamıştır. Cronbach Alfa Katsayısı, ölçekte yer alan soru grubunun varyanslarına bağlı olarak homojen bir yapıyı açıklamak üzere bir bütün oluşturup oluşturmadıklarını araştırır (Cronbach, 1951). Tablo 1'de görüldüğ üü üzere her bir ölçeğin ayrı ayrı güvenirlik katsayısı 0.80 ' den yüksek olması $(0.911 ; 0.925 ; 0.935)$ her bir ölçeğin güvenirlik açısından oldukça yüksek değerlere sahip olduğu görülmektedir. 
Tablo 1: Tüm Ölçeklerin Güvenirlilik Sonuçları

\begin{tabular}{lcc}
\hline \hline Madde (Soru) Sayısı & Sayı (N) & Cronbach Alpha (a) \\
\hline İşten Ayrılma Ölçeği (3) & 200 & 0.911 \\
Ücret Tatmini Ölçeği (13) & 200 & 0.925 \\
Yetenek Yönetimi (16) & 200 & 0.935 \\
\hline \hline
\end{tabular}

Güvenirlik analizlerinin gerçekleştirilmesinden sonra her bir ölçek grubunun sahip oldukları alt faktör ya da faktörlerin ortaya çıkarılması hedeflenmektedir. İlk olarak yetenek yönetimi ölçeğinin sahip olduğu genel ölçek yapısına bakılmış ve sahip olduğu alt faktör gruplar ortaya çıkarılmıştır.

Ancak açıklayıcı faktör analizinin gerçekleştirilebilmesi için önce varsayımlarının sağlanması gerekmektedir. Bu varsayımlar, Kaiser Meyer Örneklem yeterliliği ölçütü ve Bartlett's testi ile gerçekleştirilmiştir.

KMO ölçütü örneklem büyüklüğünün analiz için yeterli olup olmadığını açıklamaktadır. KMO 0 ile 1 arasında değer alır ve 1 e ne kadar yakınsa örneklem o kadar faktör analizine uygundur. KMO değerinin 0.50'den büyük olması gerek şarttır. Bartlett testi (Bartlett, 1950) ise veri matrisinin birim matris olup olmadığına, değişkenler arasındaki korelasyonun yeterli olup olmadığına karar verir. Tüm korelasyon katsayıları sıfırdır boş hipotezini test eder, p değeri < 0,05 ise veri seti faktör analizi için uygun olduğu kabul edilir. Tablo 2'ye göre İA ile gösterilen İşten Ayrılma Ölçeğinin, ÜC. T ile gösterilen Ücret Tatmini Ölçeği ve son olarak Y.Y ile gösterilen yetenek yönetimi ölçeği sorularının her birinin ve toplam değerlerinin sahip olduğu değerlerin $0.6>$ yüksek olması bu varsayımın sağlandığının bir göstergesidir.

Tablo 2: Tüm Ölçek Soruları MSA Değerleri

\begin{tabular}{lrlrlr}
\hline \hline Toplam MSA* & 0.735 & Toplam MSA & 0.951 & Toplam MSA & 0.921 \\
\hline İA. Ö1 & 0.692 & Üc.T.1 & 0.935 & Yetsoy1 & 0.912 \\
İA.Ö2 & 0.854 & Üc.T.2 & 0.963 & Yetsoy2 & 0.899 \\
İA.Ö3 & 0.696 & Üc.T.3 & 0.946 & Yetsoy3 & 0.919 \\
& & Üc.T.4 & 0.941 & Yetsoy4 & 0.88 \\
& & Üc.T.5 & 0.95 & Yetsoy5 & 0.919 \\
& Üc.T.6 & 0.964 & Yetsoy6 & 0.942 \\
& Üc.T.7 & 0.962 & Yetsoy7 & 0.929 \\
& Üc.T.8 & 0.968 & Yetsom1 & 0.946 \\
& & Üc.T.9 & 0.969 & Yetsom2 & 0.925 \\
& Üc.T.10 & 0.947 & Yetsom3 & 0.926 \\
& Üc.T.11 & 0.96 & Yetsom4 & 0.907 \\
& Üc.T.12 & 0.941 & Yetsom5 & 0.915 \\
& Üc.T.13 & 0.925 & Yetsom6 & 0.913 \\
& & & Yetsom7 & 0.949 \\
& & & Yetsom8 & 0.904 \\
\hline
\end{tabular}

*MSA=Örneklem Yeterlilik Ölçeği

Aynı şekilde tüm ölçeklerin Bartlett test p değerlerinin $0.05^{\prime}$ ten (Tablo 3) oldukça düşük değerler olması her bir ölçeğin kendi içinde güçlü korelasyon ilişkileri barındırdığını bize göstermektedir.

Tablo 3: Tüm Ölçekler Bartlett Testi

\begin{tabular}{lrr}
\hline \hline \multicolumn{1}{c}{$\mathbf{X}^{\mathbf{2}}$} & $\mathbf{d f}$ & $\mathbf{p}$ \\
\hline İşten Ayrılma Ölçeği- 431.170 & 3.000 & $<.001$ \\
Yetenek Yönetimi -3818.392 & 120.000 & $<.001$ \\
Ücret Faktörü Ölçeği-3869.397 & 78.000 & $<.001$ \\
\hline
\end{tabular}




\section{Ercan Öge}

Tablo 4: Yetenek Yönetimi Faktörleri ve Yükleri

\begin{tabular}{lcc}
\hline \hline & Faktör 1 Faktör 2 \\
\hline Yetsoy1 & 0.597 & \\
Yetsoy2 & 0.688 & \\
Yetsoy3 & 0.723 & \\
Yetsoy4 & 0.791 & \\
Yetsoy5 & 0.814 & \\
Yetsoy6 & 0.803 & \\
Yetsoy7 & 0.663 & \\
Yetsom1 & & 0.796 \\
Yetsom2 & & 0.832 \\
Yetsom3 & & 0.763 \\
Yetsom4 & & \\
Yetsom5 & 0.756 & 0.614 \\
Yetsom6 & & 0.608 \\
Yetsom7 & & 0.608 \\
Yetsom8 & & 0.567 \\
\hline
\end{tabular}

İşten Ayrılma ve Ücret Tatmini ölçekleri ise tek bir faktör yapısı üzerinde oldukça yüksek açıklayıcıllğa sahiptir. Çalışmada kullanılan anket soruları yetenek yönetimini hem somut hem soyut algı olarak iki alt faktörden oluşturularak kurgulanmıştır. Soruların 2 faktörlü bir kurguda alt faktör gruplarına dağıldığı Tablo 4 ile gösterilmektedir. Tabloya göre Yetsom5 ile kodlanmış değişken iki yük değeri arasındaki farkın oldukça düşük olması sebebiyle $(0,756-0,614)$ bu maddelerin binişik olduğu ve bu durumunda tek bir özelliği ölçmediğini de gösterdiğinden bu madde analiz dışı bırakılmıştır.

Tablo 5: Ölçeklerin Açılanan Varyans Yüzdeleri

\begin{tabular}{|c|c|c|c|c|}
\hline & & Toplam & $\%$ Açıklanan Varyans & \% Kümülatif \\
\hline & 1 & 9.91 & 70.78 & 70.78 \\
\hline Yetenek Yönetimi Ölçeği & 2 & 0.89 & 6.37 & 77.16 \\
\hline İşten Ayrılma Ölçeği & 1 & 2.55 & 85.06 & 85.06 \\
\hline Ücret Tatmini Ölçeği & 1 & 10.67 & 82.05 & 82.05 \\
\hline
\end{tabular}

Yetenek Yönetimi Ölçeği 2 boyuttan oluşmaktadır. Bu boyutlar somut ve soyut yetenek yönetimi algılarıdır. Bu ölçek 2 boyutta toplam varyansın birlikte \%70,78'ini açıklamaktadır. İşten Ayrılma ve Ücret tatmini ölçekleri tek bir boyutta kurgulanmış ölçeklerdir ve işten ayrılma ölçeği tek boyutla varyansın \%85'ini ücret tatmini ölçeği ise tek boyutuyla \%82'sini açıklamaktadır (Tablo 5).

\section{Regresyon analizleri ve aracı etki rolü}

Bağımsız değişken ya da değişkenleri arasında bir aracılık etkisinden söz edebilmek için bazı koşulların sağlanması gerekir. Baron ve Kenny'nin (1986) tarafından önerilen adımlar aşağıdaki gibidir;

Bağımsız değişkenin, aracı değişken üzerinde bir etkisi olmalıdır.

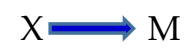

Bağımsız değişken, bağımlı değişken üzerinde etkili olmalıdır.

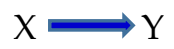

Aracı değişken, ikinci adımdaki regresyon analizine dâhil edildiğinde; bağımsız değişkenle bağımlı değişken arasında anlamlı olmayan ilişki ortaya çıkarsa tam aracılık etkisinden; bağımsız değişken ile bağımlı değişken arasındaki ilişkide azalma meydana gelirse kısmi aracılık etkisinden söz edilebilir.

$\mathrm{X}+\mathrm{M} \longrightarrow \mathrm{Y}$ (Toplam Etki). 
Tablo 6: Tüm Faktörlerin Birlikte Korelasyon İlişkileri

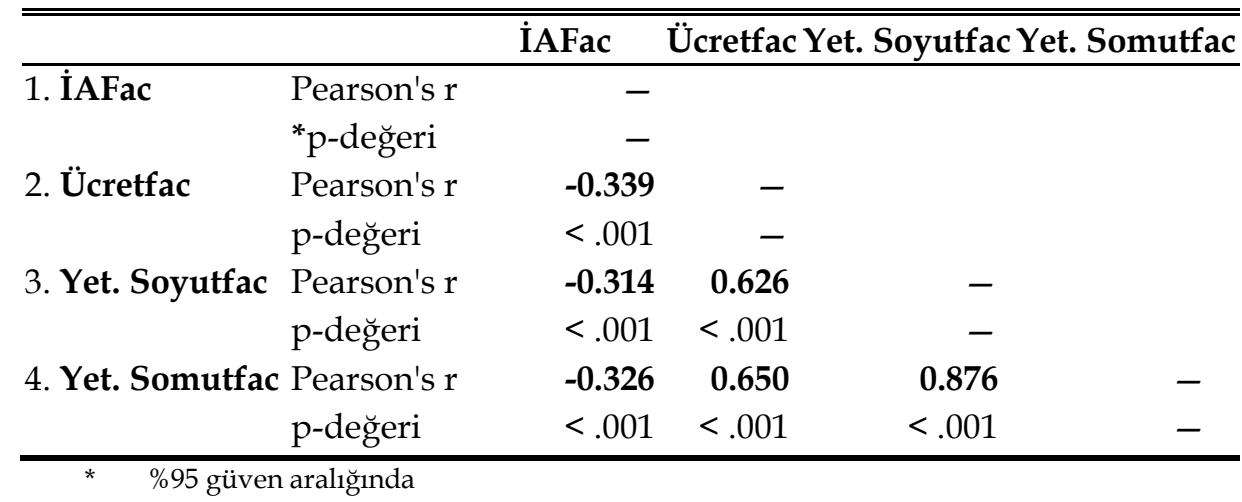

Tablo 6 ile gösterilen korelasyon tablosu; bağımlı, bağımsız ve aracı olarak düşünülen tüm faktörler arasındaki ilişki gücünü yönünü ve anlamlılığını göstermektedir. İlişkiler ağında bağımlı değişken olarak yer alan işten ayrılma algısı ile hem somut hem de soyut yetenek yönetim ilişkisi negatif yönlü orta seviyeli bir ilişkidir $(-0.326 ;-0.314)$. Somut ve soyut yetenek yönetimi faktörlerinin kendi aralarındaki ilişkisi ise oldukça yüksek pozitif korelasyondadır. Yetenek yönetimi uygulamaları güçlü olan kurumlarda işten ayrılma niyetinin daha düşük veya tam tersi bir şekilde yani yetenekleri bulan ama güçlendiremeyen ve elde tutamayan kurumlarda ise işten ayrılma niyetinin daha yüksek şekilde ortaya çıkacağı söylenebilir. Çalışmada aracı etkinin yani ücret faktörünün böyle bir rolü olup olmadığının kontrolünde ise çeşitli regresyon denklemleri kullanılarak tahminler gerçekleştirilmiştir. Regresyon analizinin uygulanabilmesi için gerekli varsayımlar mevcuttur. Bu varsayımlardan ilki, gözlemler birbirinden bağımsız olmalı ve normal dağılmalıdır. Bu problem, toplanan verilerin faktör analizine girmesi sebebiyle elde edilen faktörler zaten normal dağılıma uygun türetildiğinden çözülmüş bir varsayımdir.

Tablo 7: Özet Model Tablosu

\begin{tabular}{lllrrr}
\hline \hline Model & $\mathbf{R}$ & $\mathbf{R}^{\mathbf{2}}$ & Düzeltilmiş $\mathbf{R}^{\mathbf{2}}$ & $\mathbf{R}^{\mathbf{2}}$ & \multicolumn{2}{c}{$\mathbf{F}$} \\
\hline $\mathrm{H}_{1}$ Soyut & 0.314 & 0.099 & 0.094 & $(0.01)$ & 21.706 \\
Ho Somut & 0.326 & 0.106 & 0.102 & $(0.02)$ & 23.497 \\
\hline
\end{tabular}

Tablo 8: Katsayılar Tablosu

\begin{tabular}{|c|c|c|c|c|c|c|}
\hline Mode & & $\begin{array}{l}\text { Standardize } \\
\text { Edilmemiş B değeri }\end{array}$ & $\begin{array}{l}\text { Standart } \\
\text { Hata }\end{array}$ & $\begin{array}{l}\text { Standardize B } \\
\text { Değeri }\end{array}$ & $\mathbf{t}$ & $\mathbf{p}$ \\
\hline \multirow[t]{2}{*}{$\overline{\mathrm{H}_{1}}$} & Kesişim & 4.227 & 0.321 & & 13.163 & $3<.001$ \\
\hline & Yet. Soyutfac & -0.059 & 0.013 & -0.314 & -4.659 & $<.001$ \\
\hline \multirow[t]{2}{*}{$\mathrm{H}_{1}$} & Kesişim & 4.215 & 0.307 & & 13.728 & $3<.001$ \\
\hline & Yet. Somutfac & -0.051 & 0.011 & -0.326 & -4.847 & $<.001$ \\
\hline
\end{tabular}

Tablo 7 hem soyut hem de somut yetenek yönetimi algısının işten ayrılma bağımlı değişkeni üzerinde regresyon analizi ile ne kadarlık bir açıklayıcılığa sahip olduğunu belirtmektedir. Soyut algının $\mathrm{R}^{2}$ değeri 0,09 ve somut algının ise $0,106^{\prime}$ dır. Her iki analiz model de Anova testinden anlamlı olarak çıkmıştır ki bu durum bize regresyon analiz sonuçlarının güvenle kullanılabileceğini göstermektedir. Tablo 8 ise hem soyut hem de somut faktörün anlamlı bir şekilde işten ayrılma ölçeği üzerinde etkisi olduğunu göstermektedir $(p<0,05)$. Çalışmada kurgulanan ana hipotezlerden biri hem somut hem de soyut faktörlerin işten ayrılma üzerinde anlamlı seviyede belirli bir açıklayıcılığa (Şekil 2 ve 3) sahip olmalarıdır. Normal Dağılımın sağlanması koşulunun ardından hataların yaklaşık normal dağılması ve varyansların homojenliği görsel sunumlarla gösterilmiş ve şartlara yaklaşık oldukları görülmektedir. 

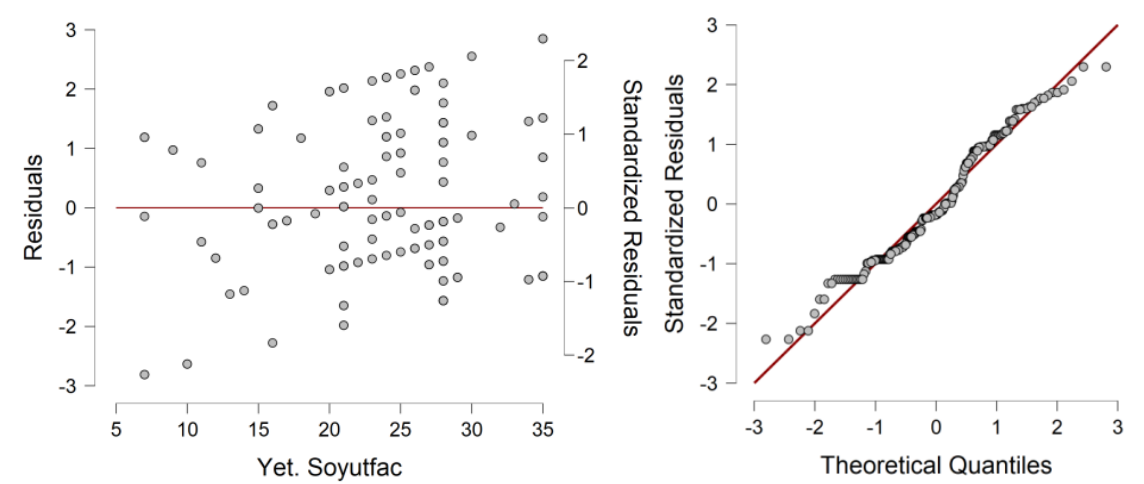

Şekil 2: Soyut Yetenek ile İşten Ayrılma Ölçeği
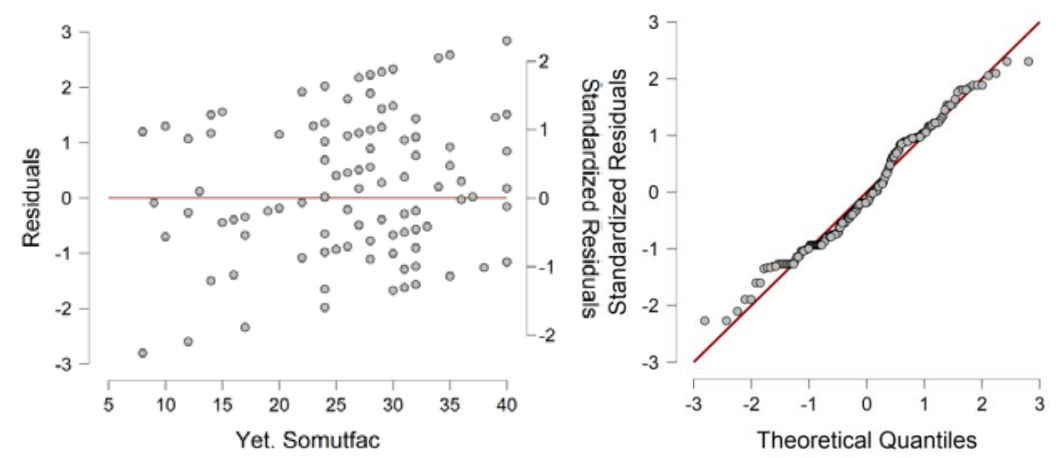

Şekil 3: Somut Yetenek ile İşten Ayrılma Ölçeği

Aracı etkinin var olup olmadığının tespiti için bir diğer önemli aşama $X$ bağımsız değişkeninin $M$ yani mediatör değişken üzerinde anlamlı bir etkisinin olması gerekmektedir. Çalışma değişkenlerimiz ile düşünüldüğünde yetenek yönetimi alt faktörlerinden soyut faktörün daha sonra ise somut faktörün aracı değişken olarak düşünülen ücret faktörü üzerindeki etkisi araştırılmıştır.

Tablo 9: Özet Model Tablosu

\begin{tabular}{lllll}
\hline \hline Model & $\mathbf{R}$ & $\mathbf{R}^{\mathbf{2}}$ & Düzeltilmiş $\mathbf{R}^{\mathbf{2}}$ & Anova F \\
\hline $\mathrm{H}_{0}$ & 0.000 & 0.000 & 0.000 & \\
$\mathrm{H}_{1}$-Soyut Faktör & 0.626 & 0.392 & 0.389 & $127.5(<0.01)$ \\
$\mathrm{H}_{1}$-Somut Faktör & 0.650 & 0.423 & 0.420 & $144.9(<0.01)$ \\
\hline
\end{tabular}

Tablo 10: Katsayılar Matrisi

\begin{tabular}{|c|c|c|c|c|c|c|c|c|}
\hline \multicolumn{2}{|c|}{ Model } & \multicolumn{2}{|c|}{$\begin{array}{c}\text { Standardize } \\
\text { Edilmemiş B değeri }\end{array}$} & \multicolumn{2}{|c|}{ Standart Hata } & \multirow[t]{2}{*}{$\begin{array}{c}\text { Standardize B } \\
\text { Değeri }\end{array}$} & \multirow{2}{*}{$\frac{\mathbf{t}^{\mathbf{t}}}{1.050}$} & \multirow{2}{*}{$\begin{array}{c}\mathbf{p} \\
0.295\end{array}$} \\
\hline $\mathrm{H}_{1}$ & Kesişim & 0.244 & & 0.232 & & & & \\
\hline & Yet. Soyutfac & 0.104 & & 0.009 & & 0.626 & 11.292 & $<.001$ \\
\hline \multirow[t]{2}{*}{$\overline{\mathrm{H}_{1}}$} & Kesişim & & 0.260 & 0.217 & & 1.196 & & 0.233 \\
\hline & Yet. Somutfac & & 0.091 & 0.008 & 0.650 & 12.039 & & $<.001$ \\
\hline
\end{tabular}

Tablo 9'de hem somut hem de soyut yetenek yönetimi algısının ayrı ayrı aracı değişken olarak düşünülen ücret faktörü üzerindeki nedensellik ilişkisi araştırılmıştır. Her ikisinin de anlamlı F değerleri ve bağımlı değişken üzerinde oldukça güçlü sayılabilecek $\mathrm{R}^{2}$ değerleri mevcuttur. Bu değer soyut faktör ile 0.392 ve somut faktör ile $0.423^{\prime}$ tür.

Tablo $10^{\prime}$ da ise sırasıyla hem soyut hem de somut faktörlerin mediatör değişken arasında yazılabilen regresyon denklemini ve bağımlı değişken üzerinde anlamlı olup olmadığını göstermektedir. Her ikisi de anlamlı etkiye sahiptir $(\mathrm{p}<0.01)$. 


\section{Ercan Öge}
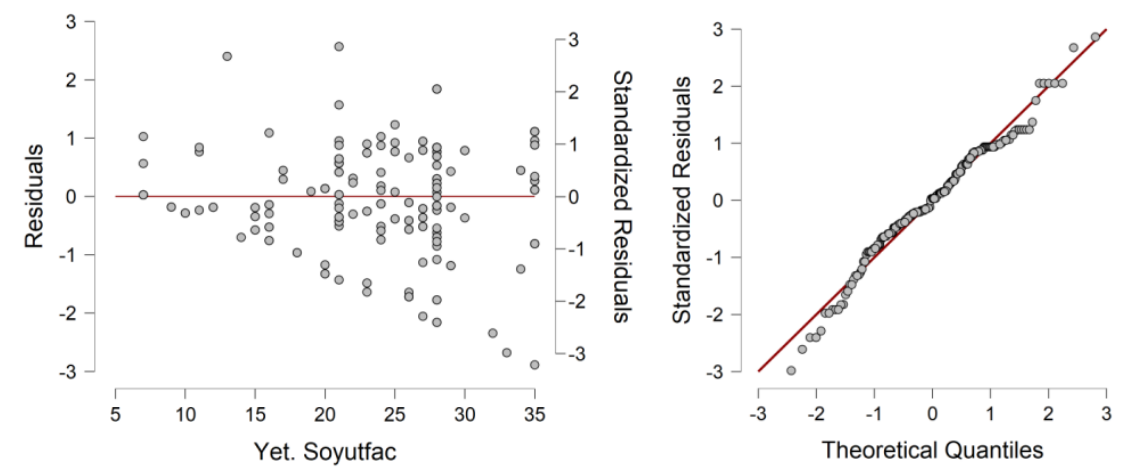

Şekil 4: Soyut Yetenek ile Ücret Faktörü Ölçeği
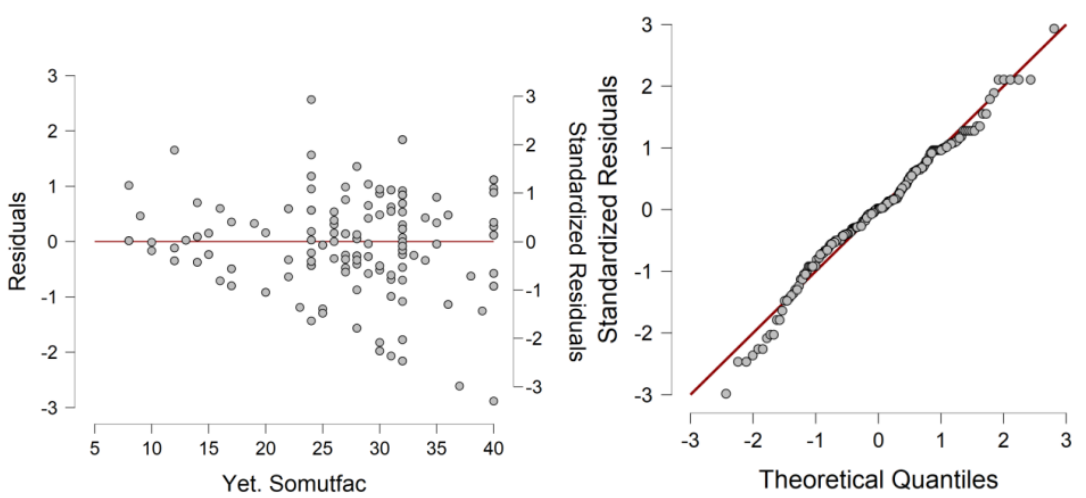

Şekil 5: Somut Yetenek ile Ücret Faktörü Ölçeği

Şekil 4 ve Şekil 5'e göre regresyon denklemlerinin yorumlanıp kullanılabilmesi için varsayımlarının sağlanması gerekmektedir. Bu durum sağlanmaktadır.

Son olarak $\mathrm{X}$ ile $\mathrm{M}^{\prime}$ in birlikte $\mathrm{Y}$ üzerindeki etkisi ölçümlendiğinde yani hem somut hem de soyut yetenek yönetimi algısı ücret tatmini ile birlikte bağımlı değişken olarak düşünülen işten ayrılma niyeti üzerindeki etkisi incelenmiştir.

Tablo 11: Model Tablosu

\begin{tabular}{|c|c|c|c|c|}
\hline Model & $\mathbf{R}$ & $\mathbf{R}^{2}$ & Ayarl & 2 Anova \\
\hline $\mathrm{H}_{1}$ Soyut+UcretFaktörü & 0.364 & 0.132 & 0.123 & $15.014(<0.01)$ \\
\hline $\begin{array}{l}\mathrm{H}_{1} \\
\text { Somut+ÜcretFaktörü }\end{array}$ & 0.366 & 0.104 & 0.126 & $15.283(<0.01)$ \\
\hline
\end{tabular}

Tablo 12: Katsayılar Tablosu

\begin{tabular}{|c|c|c|c|c|c|c|}
\hline Moc & & $\begin{array}{l}\text { Standardize } \\
\text { Edilmemiş B değeri }\end{array}$ & i Standart Hata & $\begin{array}{l}\text { Standardize B } \\
\text { Değeri }\end{array}$ & $\mathbf{t}$ & $\mathrm{p}$ \\
\hline \multirow{3}{*}{$\mathrm{H}_{1}$} & (Intercept) & 4.292 & 0.317 & & 13.549 & $9<.001$ \\
\hline & Ücretfac & -0.266 & 0.097 & -0.235 & -2.757 & 0.006 \\
\hline & Yet. Soyutfac & -0.032 & 0.016 & -0.167 & -1.968 & 0.049 \\
\hline \multirow{3}{*}{$\mathrm{H}_{1}$} & (Intercept) & 4.280 & 0.304 & & 14.079 & \\
\hline & Ücretfac & -0.251 & 0.099 & -0.221 & -2.535 & 0,04 \\
\hline & $\begin{array}{l}\text { Yet. Somut } \\
\text { fac }\end{array}$ & -0.029 & 0.014 & -0.182 & -2.085 & 0,03 \\
\hline
\end{tabular}

Tablo 11'a göre soyut yetenek yönetimi algısı ve ücret faktörü birlikte 0.132 'lik bir $\mathrm{R}^{2}$ değeri yani açıklayıcılığa aynı şekilde somut faktörün ücret faktörü birlikte $0.134^{\prime}$ lik bir $\mathrm{R}^{2}$ değerine sahiptir. Tablo 
12'e göre bağımsız değişken olarak yer alan her bir faktörde bağımlı değişken üzerinde anlamlı etkiye sahiptir (<0.05).

Çalışma ile elde edilen en önemli bulgu ücret faktörünün mediatör yani aracı etkisine sahip olmasıdır. $\mathrm{Bu}$ tespit $\mathrm{X}$ bağımsız değişkenlerine (somut ve soyut yetenek yönetimi algısı faktörleri) ait beta katsayılarındaki azalmanın ölçülmesi ile ortaya çıkmıştır. İlk olarak soyut yetenek yönetimi algısı için belirtilirse $-0.314 \quad(\mathrm{p}<0.001)^{\prime}$ lik beta katsayısı $-0.167 \quad(\mathrm{p}=0.049)^{\prime}$ ye düşmüştür. Bu aracı değişkenin bağımsız değişkenin açıklayıcılığının bir kısmını alabildiğini göstermiştir. Aynı şekilde somut yetenek yönetimi algısı için belirtilirse $-0.326(p<0.001)^{\prime}$ lik beta katsayısı $-0.182(\mathrm{p}=0.038)^{\prime}$ ye düşmüştür. $\mathrm{Bu}$ durum her iki faktörümüz için de ücret faktörünün bir aracıllk rolü üstlendiği kesinleşmiştir. Ancak bu etkinin istatistiksel anlamlılığını ölçmek gerekmektedir.

Gerçekleştirilen aracılık etkinin istatistiksel olarak anlamlılı̆̆ını ve etkinliğini ölçmek için literatürde kullanılan birçok test mevcuttur. Sobel test (Sobel, 1982) ve boostrapping (Preacher ve Hayes, 2008) testleri literatürde oldukça sık kullanılanları arasındadır. Bu yöntemlerin Baron ve Kenny (1986) tarafından ortaya konulan aşamalı sürecin ötesindeki temel katkısı, varsayılan endirekt etkinin anlamlılığını doğrudan değerlendirme olanağı vermeleridir (Okan, Sarı ve İlhan-Nas, 2014). Literatürde son yillarda boostrapping methodun varsayımlardan bağımsız parametrik olmayan test olması sebebiyle bu metotla mediatör etkiye hem somut yeterliliğin bağımsız değişken olduğu hem de soyut yeterliliğin bağımsız değişken olduğu her iki durum için ayrı ayrı analiz gerçekleştirilmiştir.

Tablo 13: Aracı Etki Alt ve Üst Sınırı

\begin{tabular}{llll}
\hline & Etki & BootLLCI & BootULCI \\
Soyut Etki- Ücret Tatmini & -0.027 & -0.0508 & -0.012 \\
Somut Etki- Ücret Tatmini & -0.022 & -0.0423 & -0.010 \\
\hline
\end{tabular}

Tablo 13 ' de, soyut etki üzerinden ücret tatminin aracılık etkisi negatif yönde $-0,05$ üst değeri ve yaklaşık $-0,01$ alt değeri göstermekte ve somut etki üzerinden de çok benzer şekilde negatif yönlü olarak -0.04 üst değer ve -0,01 alt değer gibi bir azalmaya sebep olduğu görülmektedir. Sonuç itibariyle ücret faktörünün işten ayrılma üzerinde ücret faktörünün çok yüksek düzeyde olmasa da anlamlı kısmi aracillk etkisi olduğu görülmüştür.

\section{Tartışma ve sonuç}

Günümüzde dış kaynak kullanımı özellikle rakiplerine kıyasla sürdürülebilir bir rekabetçi avantaj sağlamak isteyen küçük ve orta ölçekli işletmeler için büyük önem taşımaktadır. KOBI'lerin dış kaynaklardan yoğun bir şekilde yararlanmaları beraberinde çalışmamızda yer alan tesis yönetimi sektöründeki lider kuruluş gibi işletmeleri ön plana çıarmaktadır. Bu amaçla, Türkiye'de 47.000 çalışanı ile faaliyetlerine devam eden küresel bir tesis yönetimi işletmesinin İstanbul Anadolu yakası genelindeki 16.000 çalışanı ana kütle olarak belirlenmiş ve tesis yönetimi sektörünün ülkemizin gelişmekte olan bir sektörü olması da dikkate alınmıştır.

Çalışmada, işletmelerin uyguladıkları yetenek yönetimi uygulamalarına yönelik çalışan algısının işten ayrılma niyeti üzerindeki etkisinin ve bu ilişkide ücret tatmininin bir aracı değişken olarak aracılık rolünün olup olmadığı araştırılmıştır.

Yetenek Yönetimi Algısı, Ücret Tatmini ve İşten Ayrılma Niyeti faktörlerinin birlikte değerlendirildiği ilişkiler ağında bağımlı değişken olarak yer alan işten ayrılma algısı ile hem somut hem de soyut yetenek yönetim ilişkisine yönelik negatif yönlü orta seviyeli bir ilişki söz konusudur (-0.326;-0.314). Somut ve soyut yetenek yönetimi faktörlerinin ücret tatmini ile ilişkisi ise oldukça yüksek pozitif korelasyondadır. Buna bağlı olarak yetenek yönetimi uygulamaları güçlü olan örgütlerde işten ayrılma niyetinin daha düşük veya tam tersi bir şekilde yetenek yönetimi uygulamalarının yetersiz olduğu örgütlerde ise işten ayrılma niyetinin daha yüksek şekilde olması beklenmelidir. Mediatör diğer bir ifadeyle aracı etkinin yani ücret faktörünün böyle bir rolü olup olmadığının tespitinde ise çeşitli regresyon denklemleri kullanılarak tahminler gerçekleştirilmiştir.

Yetenek yönetiminin alt boyutları olan soyut ve somut alt boyutlarının işten ayrılma niyeti, bağımlı değişkeni üzerinde yapılan regresyon analizi sonucunda; soyut algının $R^{2}$ değeri 0.09 ve somut algının ise 0.106 'dır. Her iki analiz model de Anova testinden anlamlı olarak çıkmıştır ki bu durum bize regresyon analiz sonuçlarının güvenle kullanılabileceğini göstermektedir. Katsayılar tablosu (Tablo 8) ise hem soyut hem de somut faktörün anlamlı bir şekilde işten ayrılma ölçeği üzerinde etkisi olduğunu göstermektedir $(\mathrm{p}<0.05)$. Yetenek yönetiminin alt boyutları olan soyut ve somut alt boyutlarının ayrı ayrı aracı değişken olarak düşünülen ücret faktörü üzerindeki nedensellik ilişkisine bakıldığında ise; 
her ikisinin de anlamlı $\mathrm{F}$ değerleri ve bağımlı değişken üzerinde oldukça güçlü sayılabilecek $\mathrm{R}^{2}$ değerleri mevcuttur. Bu değer soyut faktör ile 0.392 ve somut faktör ile 0.423 'tür. Katsayılar tablosu (Tablo 10) ise sirasıyla hem soyut hem de somut faktörlerin ücret tatmini üzerinde anlamlı etkiye sahiptir $(\mathrm{p}<0.01)$.

Bağımsız (yetenek yönetimi algısı) ve aracı değişkenin (ücret tatmini algısı) bağımlı değişken (işten ayrılma niyeti) üzerindeki etkisi ölçümlendiğinde ise soyut yetenek yönetimi algısı ve ücret tatminin birlikte 0.132 'lik bir $\mathrm{R}^{2}$ değeri, aynı şekilde somut faktörün ücret tatmini ile birlikte $0.134^{\prime}$ lik bir $\mathrm{R}^{2}$ değerine yani açıklayıcılığa sahiptir. Katsayılar tablosuna (Tablo 12) göre bağımsız değişken olarak yer alan her bir faktör (yetenek yönetimi algısı ve ücret tatmini) bağımlı değişken üzerinde anlamlı etkiye sahiptir $(<0.05)$. Sonuçlar değerlendirildiğinde çalışmada elde edilen en önemli bulgu, ücret tatminin oldukça güçlü bir mediatör yani aracı etkisine sahip olduğudur. Böyle bir sonuca, $X$ bağımsız değişkenlerine (somut ve soyut yetenek yönetimi algısı faktörleri) ait beta katsayılarındaki azalmanın ölçülmesi neticesinde varılmıştır. İlk olarak soyut yetenek yönetimi algısı için belirtilirse -0.314 $(\mathrm{p}<0.001)^{\prime}$ lik beta katsayısı $-0.167(\mathrm{p}=0.049)^{\prime}$ ye düşmüştür. Bu aracı değişkenin bağımsız değişkenin açıklayıcılığının bir kısmını alabildiğini göstermiştir. Aynı şekilde, somut yetenek yönetimi algısı için de belirtilirse $-0.326(\mathrm{p}<0.001)^{\prime}$ lik beta katsayısı $-0.182(\mathrm{p}=0.038)^{\prime}$ ye düşmüştür. Bu sonuçlara bağlı olarak, yetenek yönetimi algısı ve işten ayrılma niyeti faktörleri için ücret faktörünün bir aracılık rolü üstlendiği söylenebilir.

Çalışmamızın değişkenlerini oluşturan; yetenek yönetimi, ücret tatmini ve işten ayrılma niyeti ilişkisine yönelik ayrı ayrı ya da ikili ilişkiler halinde incelenmiş çalışmalar olmasına rağmen, bu üç kavramın ilişkisini bir arada ele alan bir çalışmanın olmadığından yola çıkılarak, literatürde ikili ilişkilere (yetenek yönetimi işten ayrılma ilişkisi ve ücret tatmini işten ayrılma ilişkisine) yönelik çalışmalar derlenerek çalışmamızın bulguları değerlendirilmiştir. Bahadınlı Serim (2013) "İşletmelerde Yetenek Yönetimi Uygulamalarının Çalışanların İş Tatmini ve Örgüte Bağlılıkları Üzerindeki Etkisi (Illaç, Tekstil Ve Otomotiv Sektörlerinde Araştırma)" adlı doktora tez çalışmasında yetenek yönetimi uygulamaları algısının çalışanların iş tatmini ve örgüte bağlılıkları üzerinde etkili olduğu; Akbaş (2013) tarafından yapılan "The Relationship Between Talent Management and Retention of Employees: A Case Study in Banking Sector" adlı yüksek lisans tez çalışmasında, örgütlerin çalışanların yeteneklerine yönelik yaptıkları uygulamaların çalışanların işletmede kalma isteğini arttırdığı; Tümen (2014) "İşletmelerde İnsan Kaynağının Değerlendirilmesi Açısından Yetenek Yönetimi Yaklaşımı" adlı yüksek lisans tez çalışmasında örgütlerin yetenek yönetimini doğru uygulamaları halinde bu durumun çalışanların işten ayrılma niyetini azalttığı; Aslantaş (2016), "Yetenek Yönetiminin İşe Adanma, Performans ve İşten Ayrılma Niyetine Etkisi: Bankacılık Sektörü Örneği" adlı doktora tez çalışmasında yetenek yönetiminin ile işten ayrılma niyeti ile negatif yönlü anlamlı ilişkisi olduğu; Boz (2016) "Yöneticilerin Yetenek Yönetimi Yetkinliklerinin İşten Ayrılma Niyeti ile İlişkisinde Duygusal Bağlılık, Çalışmaya Tutkunluk ve İş Tatmininin Aracılık Etkisi: Bankacılık Sektöründe Bir Araştırma" adlı doktora tezinde yetenek yönetimi algılarının doğrudan işten ayrılma niyetini etkilediği; Tarakçı ve Öneren (2016) yaptıkları çalışmada, yetenek yönetiminin örgütsel bağlılık alt boyutları ile iş tatminini istatistiksel olarak anlamlı bir şekilde ve pozitif yönde, işten ayrılma niyetini ise istatistiksel olarak anlamlı bir şekilde ve negatif yönde etkilediği; Türk ve Akbaba (2017) yaptıkları çalışmada, çalışanların soyut ve somut yetenek yönetimi algılarının artmasının örgüte uyum sağlamalarını arttırmakta ve işten arttırma niyetlerini azalttı̆̆ı; Alyay (2019) "Yetenek Yönetiminin Örgütsel Bağlllık Üzerine Etkisi ve Bursa Otomotiv Sektöründe Bir Uygulama" adlı yüksek lisans tez çalışmasında yetenek yönetimine yönelik olan memnuniyetin daha yüksek seviyelerde bulunması halinde çalışan kaybının daha kolay atlatılmasını sağlayacağı; Ertekin (2019), "Yetenek yönetimi, işten ayrılma niyeti ve örgütsel bağlılık ilişkisi: İlaç sektöründe bir işletme araştırması" adlı yüksek lisans tez çalışmasında yetenek yönetimi ile işten ayrılma niyeti ile negatif yönlü anlamlı ilişki olduğu; Yeni (2020) yaptığı "Algılanan Yetenek Yönetiminin İşten Ayrılma Niyetine Etkisinde Duygusal Bağlllı̆̆ın Rolü: Sağlık Sektöründe Bir İnceleme" adlı doktora tez çalışmasında algılanan yetenek yönetiminin işten ayrılma niyetini negatif yönde ve anlamlı olarak etkilediği; Abdul Latif, Saraih, \& Harada'nın (2020) Malezya'daki “Bilgi ve İletişim Endüstrisinde Yetenek Yönetimi ve İşten Ayrılma Niyeti: İşe Gönülden Adanmanın Moderatör Etkisi" adlı çalışmalarının araştırma sonuçlarının, yetenek yönetimi uygulamalarının Malezya'daki Bilgi ve İletişim Endüstrisindeki çalışanları işten ayrılma niyetlerini etkilediğini kanıtlar nitelikte olduğunu ve yetenek yönetimi uygulama veya stratejilerinin işten ayrılma niyetini düşürebileceğini; Dalahmeh, Heder ve Dajnoki (2020) "Yetenek Yönetimi Uygulamalarını Bilgi ve İletişim Teknolojileri (BİT) Sektöründe Çalışanın İşten Ayrılma Niyetine Etkisi: Ürdün Örneği" adlı çalışmalarında sonuçlara bağlı olarak, yetenek yönetimi uygulamalarının, çalışanın bir organizasyondan ayrılma niyetini önemli ölçüde etkilediğini, dolayısıyla, işletmelerin yetenek yönetimi uygulamalarını uyguladıklarında, çalışanın işten ayrılma niyetinin azaldığı sonucuna ulaşmışlardır. 
Ücret tatmini ile işten ayrılma niyeti arasındaki ilişkiler incelendiğinde ise; Kanten, Kanten ve Dündar (2016) yaptıkları çalışmada, örgütün ücret yapısından tatmin duyan aynı zamanda ek yararlar ve sosyal yardımlar gibi maddi ve maddi olmayan faydalardan memnun olan işgörenlerin örgütte kalma yönünde karar vermelerinin ve örgütleriyle bütünleşmelerinin mümkün olacağını göstermekte yani işten ayrılma niyetlerinin azaldığını; Seçkin ve Çoban (2017) tarafından yapılan "Ücret Düzeyinden Tatmin, İşte Kalma Niyeti ve Yaşam Tatmini İlişkisinde Algılanan Alternatif İş Fırsatlarının Düzenleyici Rolü" ne yönelik çalışmada ücret düzeylerinden duydukları tatmin arttıkça işte kalma niyetlerinin arttı̆̆ını; Naidoo, (2017) "Güney Afrikalı BT Uzmanlarının İşten Ayrılma Niyetleri: Cinsiyet, Etnisite ve Ücret Memnuniyetinin Etkisi," adlı çalışmasında örgütsel bağlllık ve iş tatmininin işten ayrılma niyetinin en önemli yordayıcıları olduğunu ve ücret memnuniyetinin işten ayrılma niyeti üzerindeki etkisine kısmen aracılık ettiğini ortaya koyduğunu; Putri (2020) "Y kuşağı çalışanlarda ücret tatmini ve işten ayrılma niyeti" adlı çalışmasında Y kuşağı çalışanları arasında ücret tatmininin işten ayrılma niyetiyle negatif ilişkili olduğunu, ücret tatmini ne kadar yüksek olursa, Y kuşağı çalışanlarının işten ayrılma niyetlerinin o kadar düşük olacağı sonucuna ulaşmışlardır.

$\mathrm{Bu}$ araştırmanın ve diğer araştırmaların sonucunda ulaşılan bulgular dikkate alındığında, yetenek yönetimi ile işten ayrılma niyeti arasında negatif bir ilişki olduğu diğer bir ifadeyle başarılı yetenek yönetim uygulamaları ve beraberinde ücret tatminine yönelik olumlu algıları çalışanların işten ayrılma niyetlerini azaltmaktadır. Bu çalışmada ön plana çıkan en etkili sonuçlardan biri de yetenek yönetimi algısı ve işten ayrılma niyeti faktörleri için ücret faktörünün bir aracılık rolü üstlendiği, dolayısıyla örgütlerin ücret tatminin bir aracllık etkisine sahip olduğu hususunu dikkate almalarında fayda bulunmaktadır. Zira küresel iş dünyasında yaşanan hızlı dönüşüm, kurumların çalışanlarının ücretlendirmelerini nasıl düzenlediklerini yeniden düşünmelerini, yetenekli çalışanları kendi bünyelerine çekme ve elde tutmalarını ve İK harcamalarını en iyi duruma getirmelerini sağlayacak çerçeveler üretmelerini zorunlu kılmaktadır. Örgütlerin karmaşık ücret kararlarını daha yalın hale getirmeleri ve geleceğe yönelik hedeflere ulaşmalarına katkıda bulunan nitelikleri ödüllendirmeyi de içeren faktörlere öncelik vermeleri gerekmektedir. Ücret tatmini, örgüt tarafından istenilen sonuçların elde etmek amacıyla önemli temel bir mekanizma olması nedeniyle stratejik bir nitelik taşıdığı gibi, beraberinde ücret tatmininin işten ayrılma niyetini azalttığı ve örgütte kalma kararını etkilediği ifade edilmektedir (Kanten, Kanten ve Dündar, 2016, s.78-79). Sonuç olarak günümüz koşullarında yetenekli çalışanların işten ayrılmalarını önleyebilmek amacıyla örgütler, ihtiyaç duyulan yeteneklerin elde tutulması ve işletmeye çekilebilmesi için etkili bir biçimde rekabet etmelidir. Bu amaçla da ücretlerde cinsiyet eşitliği sağlamaya yönelik büyüyen küresel gelişmeleri takip etmeleri ve en iyi performansı gösteren çalışanların katkılarından dolayı tatmin edici düzeyde ödüllendirme çabalarını da etkili bir şekilde hayata geçirmelidir (Ücretlendirme Stratejisi ve Tasarımı, 2021).

\section{Hakem Değerlendirmesi / Peer-review:}

Dış bağımsız

Externally peer-reviewed

\section{Çıkar Çatışması / Conflict of interests:}

Yazar çıkar çatışması bildirmemiştir.

The author has no conflict of interest to declare.

\section{Finansal Destek / Grant Support:}

Yazar bu çalışma için finansal destek almadığını beyan etmiştir.

The author declared that this study has received no financial support.

\section{Etik Kurul Onayı / Ethics Committee Approval:}

Bu çalışma için etik kurul onayı, İstanbul Aydın Üniversitesi, Etik Kurulu/Komitesinden 09/06/2021 tarihli 2021/7 sayılı karar ile alınmıştır.

Ethics committee approval was received for this study from Istanbul Aydin University, Ethics Committee on 09/06/2021 and 2021/7 document number. 


\section{Kaynakça / References}

Abdul Latif, F. D., Saraih, U. N. and Harada, Y. (2020). Talent Management and Turnover Intention: The Moderating Effect of Employee Engagement. Journal of Advanced Research in Business, Marketing, and Supply Chain Management, (Vol. 3) (Issue. 1), 10-17.

Acar, A.C. (2007). İşletmelerde Ücret Yapısının Oluşturulması ve Bir Uygulama. Literatür Yayınları.

Akbaş, İ. (2013). The Relationship Between Talent Management and Retention of Employees: A Case Study in Banking Sector. Yayınlanmamış Yüksek Lisans Tezi, Marmara Üniversitesi Sosyal Bilimler Enstitüsü, İstanbul.

Alayoğlu, N. (2010). İnsan Kaynakları Yönetiminde Yeni Dönem: Yetenek Yönetimi. Ticaret ve Turizm Eğitim Fakültesi Dergisi, Sayı 1, 68-97.

Alyay, İ. (2019). Yetenek Yönetiminin Örgütsel Bağlllık Üzerine Etkisi ve Bursa Otomotiv Sektöründe Bir Uygulama. Yayınlanmamış Yüksek Lisans Tezi, Bahçeşehir Üniversitesi Sosyal Bilimler Enstitüsü.

Aslantaş, M. (2016). Yetenek Yönetiminin İşe Adanma, Performans ve İşten Ayrılma Niyetine Etkisi: Bankacılık Sektörü Örneği. Yayınlanmamış Doktora Tezi, Dicle Üniversitesi Sosyal Bilimler Enstitüsü, Diyarbakır.

Ataay, İ. D. (1985). Ücret Tatmini ve Ücret Sistemleri. Banksis Yayınları, No:10, İstanbul.

Bahadınlı Serim H. (2013). İşletmelerde Yetenek Yönetimi Uygulamalarının Çalışanların İş Tatmini ve Örgüte Bağlılıkları Üzerindeki Etkisi (İlaç, Tekstil ve Otomotiv Sektörlerinde Araştırma). Yayınlanmamış Doktora Tezi, Marmara Üniversitesi Sosyal Bilimler Enstitüsü, İstanbul.

Bano, S., Khan, A., Rehman, H. U., \& Humayoun, A. A. (2010). Schematizing Talent Management, A Core Business Issue. Far East Journal of Psychology and Business, 2(1).

Bartlett, M. S. (1950). Tests of Significance in Factor Analysis. British Journal of Statistical Psychology, Vol. 3, No. 2, 77-85.

Baron, R. M., \& Kenny, D. A. (1986). The Moderator-Mediator Variable Distinction in Social Psychological Research: Conceptual, Strategic, and Statistical Considerations. Journal of Personality and Social Psychology, 51(6), 1173.

Bayraktar, A.S. (2019). Stratejik İnsan Kaynakları Sürecinde Yetenek Yönetiminin Çalışanların Kariyer Memnuniyetine Etkisi ve Bir Uygulama. Yayınlanmamış Doktora Tezi, Zonguldak Bülent Ecevit Üniversitesi Sosyal Bilimler Enstitüsü, Zonguldak.

Boz, H. (2016). Yöneticilerin Yetenek Yönetimi Yetkinliklerinin İşten Ayrılma Niyeti ile İlişkisinde Duygusal Bağlılık, Çalışmaya Tutkunluk ve İş Tatmininin Aracılık Etkisi: Bankacılık Sektöründe Bir Araştırma. Yayımlanmamış Doktora Tezi, Akdeniz Üniversitesi Sosyal Bilimler Enstitüsü, Antalya.

Cronbach, L. J. (1951). Coefficient Alpha and the Internal Structure of Tests. Psychometrika, 16(3), 297334.

Çakır, Ö. (2006). Ücret Adaletinin İş Davranışları Üzerindeki Etkiler. Kamu İşletmeleri İşverenleri Sendikası Yayınları, Temmuz, Ankara.

Dalahmeh, M.A., Heder, M. ve Dajnoki, K. (2020). The Effect of Talent Management Practices on Employee Turnover Intention in The Information and Communication Technologies (Icts) Sector: Case of Jordan. Problems and Perspectives in Management, 18(4), 59-71.

Demir, R. (2020). İşletmelerde Performansla İlişkili Ücretlendirme. Nobel Bilimsel Eserler.

Dessler, G. (2019). İnsan Kaynakları Yönetimi. 15. Baskıdan Çeviri, Çeviri Editörleri; İrge Şener ve Melisa Erdilek Karabayi, Palme Yayınevi.

Ergeneli,A., İlsev,A., Metin Camgöz, S., Kümbül Güler,B., Bayhan Karapınar,P., Tayfur Ekmekçi, Ö., Ferendeci Özgödek,M., Gözde Özgödek,D., Atalay Odabaşı, N. ve Akşirin Borluk, Ç.N.(2014). İnsan Kaynakları Yönetim. 1. Basım, Nobel Akademik Yayıncılık Eğitim Danışmanlık Tic. Ltd. Şti.

Ergüney, Ö. (2006) “Ücret Tatmininin İsgören Tatmini ile İlişkisi ve Bir Uygulama”, Yayınlanmamış Yüksek Lisans Tezi, İstanbul Üniversitesi. 


\section{Ercan Öge}

Ertekin, E. (2019). Yetenek Yönetimi, İşten Ayrılma Niyeti ve Örgütsel Bağlllık İlişkisi: İlaç Sektöründe Bir İşletme Araştırması. Yayınlanmamış Yüksek Lisans Tezi, İstanbul Aydın Üniversitesi Sosyal Bilimler Enstitüsü, İstanbul.

Fegley, S. (2006). Talent Management Survey Report. Society for Human Resource Management Research, January, 1-30.

Fong, Y. L., \& Mahfar, M. (2013). Relationship Between Occupational Stress and Turnover Intention Among Employees in A Furniture Manufacturing Company in Selangor. Journal Technology, 64(1), 33-39.

Gürbüz, S. (2019). İnsan Kaynakları Yönetimi. 1. Baskı, Seçkin Yayıncılık.

Heneman, H.G. ve Schwab, D.P. (1985). Pay satisfaction: Itsmultidimensional nature and measurement. International Journal of Psychology. Vol. 20: 129-141.

Kanten, P., Kanten, S. ve Dündar, G. (2016). Ücret Tatmininin ve İşin Özelliklerinin İşe Gömülmüşlük Üzerindeki Etkisinde Mutluluğun Rolü. İşletme Araştırmaları Dergisi, 8/3, 64-88.

Keçecioğlu, T. ve Korkmaz Çiçek, A. (2014). Yeni İnsan Kaynakları Vizyonu: Yetenek Yönetimi Metrikleri. Uluslararası Yönetim İktisat ve İşletme Dergisi, Cilt 10, Sayı 22, 155-171.

Keçecioğlu, T. ve Aydın, G.G. (2017). Yetenek Savaşlarında İkinci Perde: Yetenek Savaşları. Umuttepe Yayınları, 2. Bask1.

Küçükusta, D. (2007). "Konaklama İşletmelerinde İşs-Yaşam Dengesinin Çalışma Yaşamı Kalitesi Üzerindeki Etkisi", Doktora Tezi. İzmir: Dokuz Eylül Üniversitesi SBE.

Li, X. (2015). The Relationship Between Organizational Justice and Various Dimensions of Pay Satisfaction. A Thesis, Master of Science, San José State University, 2015.

Luthans, F. (1998) Organizational Behavior. Irwin McGraw-Hill U.S.A.

Malhotra, N.K. (2004) Marketing Research an Applied Orientation. 4. Ed, Prentice-Hall, New Jersey.

Mobley, W.H. (1982). Employee Turnover: Causes, Consequences and Control. MA, Addison-Wesley.

Naidoo, Rennie (2017). Turnover Intentions among South African IT Professionals: Gender, Ethnicity and the Influence of Pay Satisfaction. The African Journal of Information Systems: Vol. 10: Iss. 1, Article 1.

Poyraz, K. ve Kama, B. (2008). Algılanan İş Güvencesinin, İş Tatmini, Örgütsel Bağlllık ve İşten Ayrılma Niyeti Üzerindeki Etkilerinin İncelenmesi. Süleyman Demirel Üniversitesi İktisadi ve İdari Bilimler Fakültesi Dergisi, 13(2), 143-164.

Preacher, Kristopher J., and Hayes, Andrew F. (2008). Asymptotic and Resampling Strategies for Assessing and Comparing Indirect Effects in Multiple Mediator Models. Behavior Research Methods. 40(3), 879-891.

Putri, N.H. (2020). Pay Satisfaction and Turnover Intention among Millennial Employees. International Journal of Research, Vol.7, No.11.

Okan, T., Sarı, S., \& Nas, T. İ. (2014). Yönetim Kurulu Yapısı ile Finansal Performans Arasındaki İlişkide Uluslararası Çeşitlenmenin Aracılık Etkisi. İstanbul Üniversitesi İşletme Fakültesi İşletme İktisadı Enstitüsü Yönetim Dergisi, 25(77), 39-78.

Öge, E. ve Çetin (2019). İşten Ayrilma Niyeti, Sinisizm ve Ücret Tatmini Arasindaki İlişkilerin İncelenmesi. 3rd International Congress of Eurasian Social Sciences, (3. Uluslararası Avrasya Sosyal Bilimler Kongresi), 18-21 April / Nisan 2019, Bodrum / Muğla.

Özdemir, S. ve Özdemir, Y. (2015). İşten Ayrılma Niyeti ve İşten Ayrılma Niyeti ile İlgili Akademik Çalışmaların İncelenmesi. Ankara: Gazi Kitabevi.

Seçkin, Ş. N.ve Çoban, R. (2017). “Ücret Düzeyinden Tatmin, İşte Kalma Niyeti ve Yaşam Tatmini İlişkisinde Algılanan Alternatif İş Fırsatlarının Düzenleyici Rolü", İşletme Araştırmaları Dergisi, 9(3), 134-148.

Seyfullahoğulları, Ç.A. (2018). İşten Ayrılma Niyeti. İstanbul: Türkmen Kitabevi.

Sobel, Michael E. (1982). Asymptotic Confidence Intervals for Indirect Effects in Structural Equation Models. Sociological Methodology, 13, 290-312. 
Tarakçı, H. ve Öneren, M. (2018). Yetenek Yönetiminin Örgütsel Bağlllık, İş Tatmini ve İşten Ayrılma Niyeti Üzerine Etkileri. İstanbul Journal of Social Sciences, Issue: 20.

Topalhan, T. (2014). Ücret Teorileri ve Ücret Politikaları. Matser Ofset.

Tümen, E. (2014). İşletmelerde İnsan Kaynağının Değerlendirilmesi Açısından Yetenek Yönetimi Yaklaşımı. Yayınlanmamış Yüksek Lisans Tezi, İstanbul Üniversitesi Sosyal Bilimler Enstitüsü, İstanbul.

Türk, M. ve Akbaba, M. (2017). Turizm İşletmelerinde Yetenek Yönetimi Algılamalarının Örgütsel Uyum ve İşten Ayrılma Niyeti Üzerine Etkisi. The Journal of Academic Social Science Studies, Number: 62, 465-479.

Tüzün, I. K. (2007). Antecedents of Turnover Intention Toward a Service Provider. The Business Review, $8(2), 128-135$.

Tüzüner, V. L. (2011). İnsan Kaynakları Yönetimi Faaliyetlerinde Ölçme ve Değerlendirme. 1. Baskı, Beta Basım A.Ş.

Uyargil,C., Özçelik, A.O., Acar, A.C., Dündar,G., Ataay,İ.D.., Tüzüner, V.L., Sadullah, Ö. ve Adal, Z. (2018). İnsan Kaynakları Yönetimi. 9. Baskı, Beta Yayıncılık.

Ücretlendirme Stratejisi ve Tasarımı. (2021). Erişim adresi: https://www. willistowerswatson.com/tr-.

Wayne, S.J., Shore, L.M., ve Liden, R.C. (1997). "Perceived Organizational Support and Leader--Member Exchange: Social Exchange Perspective", Academy of Management Journal, 40(1), 82--111.

Yeni, Z. (2020). Algılanan Yetenek Yönetiminin İşten Ayrılma Niyetine Etkisinde Duygusal Bağlllı̆̆ın Rolü: Sağlık Sektöründe Bir İnceleme. Yayınlanmamış Doktora Tezi, Kütahya Dumlupınar Üniversitesi Lisansüstü Eğitim Enstitüsü İşletme Anabilim Dalı.

Yücel, İ. ve Demirel, Y. (2013). Mevcut İş Alternatiflerinin İş Tatmini ve İşten Ayrılma İlişkisi Üzerinde Etkisi: "Başka Bir Yol Daha Olmalı!". Atatürk University Journal of Economics and Administrative Sciences, 27.2, 159- 177. 